\title{
SOCIAL AND PEDAGOGICAL SUPPORT OF STUDENTS WITH DISABILITIES IN HIGHER EDUCATION INSTITUTIONS
}

\section{Tetiana Spirina}

ORCID iD 0000-0003-0287-7343

$\mathrm{PhD}$ (Education), Associate Professor of the Department of Social Education and Social Work, Institute of Human Science, Borys Grinchenko Kyiv University 18/2 I. Shamo blvd., 02000 Kyiv, Ukraine t.spirina@kubg.edu.ua

\section{Barbara Grabowska}

ORCID iD 0000-0003-2558-0294

PhD. Hab.,

Faculty of Arts and Educational Science, Institute of Pedagogy Faculty of Social Sciences, University of Silesia in Katowice 62 ul. Bielska, 43-400 Cieszyn, Poland barbara.grabowska@us.edu.pl

\section{Tetiana Liakh}

ORCID iD 0000-0002-8807-0497

$\mathrm{PhD}$ (Education), Associate Professor,

Head of the Department of Social Pedagogy and Social Work, Institute of Human Science, Borys Grinchenko Kyiv University 18/2 I. Shamo blvd., 02000 Kyiv, Ukraine t.liakh@kubg.edu.ua

https://doi.org/10.28925/2518-7635.2020.5.6

\section{ABSTRACT}

The article considers the issue of education of students with disabilities in higher education institutions. It emphasizes the importance and features of social and pedagogical support that takes into consideration the main points that cause difficulties in this category in obtaining educational services. The article defines the perspective ways of solving the problems that concern the organization of support to students with disabilities in the environment of higher education institutions. Understanding the essence of social and pedagogical support of students with disabilities in higher education institutions involves, first of all, knowledge of the specifics of various types of developmental disorders, identifying 
existing problems, needs and opportunities of such students as well as creating appropriate conditions in the educational environment.

The growing number of people with disabilities in Ukraine raises a number of issues related to their adaptation, socialization, including education and employment. A special place in the system of higher education in Ukraine is occupied by the integrated form of education of students with disabilities together with other students, the main condition of which is to ensure equal access to education, extracurricular activities and equal rights to obtain the higher education.

The important component of the process of integration of youth with disabilities into society is the creation of appropriate conditions for learning and development of students with disabilities in higher education institutions, acquisition of knowledge, skills and competencies. In modern conditions, the accessibility of higher education for people with disabilities is an acute social and pedagogical problem which is associated with the formation of a holistic vision and the specifics of the socio-pedagogical process.

Key words: higher education institution, integrated group, students with disabilities, education, training

(C) Tetiana Spirina, Barbara Grabowska, Tetiana Liakh, 2020

\section{INTRODUCTION}

The most important stage on the way to personal development and professional emergence for each person, in particular for a person with a disability, is the period of learning in a higher education institution. It should be noted that the issue of access to higher education for people with disabilities is an acute social problem due to social, psychological, spatial, economic barriers and is complicated by a number of problems, including: the level of quality of general secondary education for people with disabilities; lack of conditions for combination of professional training of disabled people and their medical rehabilitation; insufficient development of the regulatory framework for the education of people with disabilities; lack of inclusive space; insufficient level of development of public consciousness to understand the problems and needs of people with disabilities and provide such students with educational and methodological literature; insufficient cohesion of people with disabilities in defending their rights including the right to education.

\section{LITERATURE REVIEW}

Kolchenko, Mazarska, Raver-Lampman studied the issues of interaction between lecturers and students with disabilities in higher education institutions; the specifics of social and pedagogical support of families with children with disabilities are the subject of research for Alekseenko, Boginskaya; Kolupaeva, 
Teslenko, Kharchenko, Shandor, Shevtsov study the problems of socialization, social rehabilitation and integration of people with disabilities in educational institutions; Wojciechowski, Nagorna, Naida, Savchenko, Skrypnyk studied the issues of integration of students with peculiarities of psychophysical development into the educational space; socio-pedagogical conditions for the integration of young people with functional limitations in the modern environment were studied by Myroshnichenko.

The subject of scientific research is such aspects of the problem as: the psychological supportofstudentswith disabilities(Tomarzhevska); education of spiritual and moral values of students with disabilities (Khoroshailo); support of students with special needs (Tchaikovsky); rehabilitation and adaptation support in higher education institutions (Avramenko, Makarova, Sushkevych, Talanchuk, Yevseyev); training of social lecturers for integration of students with peculiarities of psychophysical development into the environment of general secondary education institution (Pershko).

The priority of country should be the ensuring equal access to education, creating the necessary conditions for improving the situation of people with disabilities by involving them in full participation in all spheres of public life, addressing the issues of security and accessibility of social infrastructure, further integration of people with disabilities into society along with other citizens and the inclusion their fulfilling life of communities.

Despite the significant amount of research on the integration of people with disabilities into modern society, the issue of social and pedagogical support of students with disabilities in higher education institutions requires further in-depth study.

\section{RESEARCH FINDINGS}

For people with disabilities the higher education, a prestigious specialty, decently paid work is almost the only way to overcome the state of alienation, social isolation in which they find themselves under objective conditions related to health (Dikova-Favorska, 2015). It is education that provides an opportunity for self-realization, personal development, expanding the circle of communication, gaining new social experience and economic independence.

The integration of youth with special needs into the educational environment helps them to acquire professional knowledge, gain a profession, find personal fulfillment, achieve success in life and further career and feel themselves as members of society. To this purpose, the higher education institutions need to provide a free inclusive space in which students with disabilities can move, study and communicate safely.

The peculiarity of teaching students with disabilities in an integrated team is that, perceiving them as equals, they are subject to the same requirements as to other students. In the integrated group is impossible to slow down the pace of lecture, for example, reduce the number of pairs and their duration, simplify 
or reduce the amount of educational material, because it affects the quality of training of students with disabilities. That is why it is possible to compensate for the functional limitations that affect the quality of education of students with disabilities only by providing social and pedagogical support to them in the teaching and educational process.

Lecturers working in the integrated student environment should promote the awareness of students with disabilities that they can live a full student life, must constantly acquire knowledge about their capabilities, features, abilities and to form positive thinking for themselves.

According to statistics, out of 2.5 million students of domestic educational institutions of 1 to 4 levels of accreditation there are about 10 thousand students with disabilities (Statistical Yearbook, 2019). The Constitution of Ukraine, the UN Convention on the Rights of Persons with Disabilities guarantees the rights of people with disabilities to development, education and rehabilitation.

For social and pedagogical support of students with disabilities in higher education institutions should be created so-called barrier-free campuses with appropriate buildings, dormitories and other facilities where these students can receive technical training, assistance from psychologists, physicians and social workers.

In particular, the issue of supporting students with disabilities is one of the priorities in the educational activity of Borys Grinchenko Kyiv University. The University's strategy is to ensure equal access to quality higher education for all, regardless of their state of health. Currently, 116 students with disabilities study at the university and 23 of them study at the University College.

Student Disability Resource Center (SDRC) works to ensure that students with disabilities are provided with additional support. According to the concept of SDRC, there should be technical, psychological, pedagogical and sociopedagogical support. This support begins from the moment a person with disability applies to the University and covers the processes of preparation for admission, training and employment.

SDRC has created computerized workstations equipped with speech synthesizers as part of technical support. In particular, for students with visual impairments there is a portable Braille display, a portable 5-inch video magnifier, a desktop Braille font printer. Students with disabilities have access to adaptive technical equipment for scanning textbooks and translating them into electronic form, listening to audio recordings of lectures and creating their own recordings using a digital dictaphone. In addition, the Resource Center provides services for the formation and improvement of hearing-speech and cognitive skills through the program Live Sound.

The Resource Center is equipped with a physical unloading area. There are installed the Interactive Floor Projection System and Interactive Panels to improve the psycho-emotional background, stimulate active physical activity, psychomotor development and relaxation. The area of psychological unloading is also equipped. 
The specialists of SDRC implement special training for scientific and pedagogical workers to work in integrated groups, there are also conducted the workshops and trainings on the issue of pedagogical interaction with students with disabilities. Psychological and socio-pedagogical support includes psychological diagnosis, monitoring of personal development and social situation of students, promotes the socialization of students with disabilities by involvement in all spheres of public life. There are the tutoring and volunteer support from SDRC specialists, students and lecturers for the students with disabilities throughout their studying at the University.

Students with disabilities have certain problems that have formed in previous periods of life and study that significantly affect not only on their cognitive activity but also their integration into the educational environment. Thus, the social and pedagogical support of students with disabilities in the educational process in higher education institution becomes relevant (Talanchuk, 2004). Commonly, these students are very inquisitive and diligent but have certain problems such as: gaps in knowledge; difficulties in overcoming environmental barriers and the perception of educational material in the conventional form; reduced efficiency, impaired concentration; increased anxiety, vulnerability, emotional instability, fatigue and exhaustion, vulnerability to infectious diseases and therefore problems with attending the sessions; low level of physical training; lack of sociability; insufficient orientation in society, low self-esteem and social activity; low level of motivation to achieve the goal, etc.

To work with such people, it is necessary to introduce special methods, pedagogical technologies and adaptive technical means into the teaching and educational process as each student with disability has certain features and limitations that complicate learning.

The general situation regarding the education of students with disabilities in Ukraine is characterized by the fact that out of 100 young people with disabilities who could study, only a few percent receive higher education today. Fear of unsuitability to the social environment, lack of barrier-free access, lack of specially adapted public transport for low-mobility groups, special devices, equipment and undeveloped teaching methods for students with disabilities is not a complete list of reasons for the small number of students with disabilities in higher education. (Pichuhina, 2009). The analysis of the scientific literature provides the basis to conclude that the motivation of entrants with disabilities to enroll a higher education institution is reduced, mainly due to the experience of integrated education in general secondary education. That is why the professional orientation with the definition of individual abilities and features of mastering a profession and the desire to learn are the important components of socio-pedagogical work at the stage of preparing young people with disabilities to university admission (Bohinska, 2013).

Yulia Bohinska signed out the perspective ways of the social and pedagogical support system's improvement for people with disabilities in higher education institutions: development of the network of different types and kinds 
of structural subdivisions concerning work with the disabled people; training of specialists; improvement the material, technical and rehabilitation bases, adherence to the principles of humanism, accessibility, continuity, systematics, tolerance, individuality (Bohinska, 2013). The researcher believes that the organization of education and socialization of students with disabilities and methodological readiness of academic and teaching staff to work with them provide three groups of conditions: structural-functional, adaptiveintegration and psychological-pedagogical. The scientist also singles out the social accessibility of the environment and information provision as the main opportunity for higher education for young people with disabilities as well as educational accessibility that depends on the legislative provision of the opportunity to study in higher education institutions.

Modern education is designed to ensure a high level of intellectual and professional development of future professionals. Taking into account the proclamation of the idea of accessibility and development of information technologies, nowadays more and more higher education institutions provide distance learning for entrants with disabilities. Nowadays, distance learning is carried out using technologies such as Internet in voice and text modes, e-mail, telephone and facsimile, video conferences using the platforms Meet and Zoom that provide daily communication between students with disabilities and scientific and pedagogical employees.

Borys Grinchenko Kyiv University has established the Center for Distance Learning Technologies. The main tasks of the Center are: ensuring the work of distance learning studios; conducting workshops and online sessions for lectures on the preparation, creation (recording, editing) and implementation of video materials (video lectures, webinars, screencasts, video tutorials, online conferences); consulting on the organization of e-learning, electronic cooperation and communication using WebEx software; conducting research on e-learning; development of an ecosystem of continuous professional development of lecturers.

To ensure equal access of young people with disabilities to higher education, it is recommended to form a positive public opinion on the feasibility of joint education of healthy students and students with disabilities, to develop teaching materials, introduce special methods, pedagogical technologies, use adaptive technical means and complex programs of integration, adaptation and selfrealization of young people with disabilities. Dikova-Favorska pays attention to the accessibility of the environment of higher education institutions as an important condition for promoting social adaptation and adaptation of students with disabilities to the educational process (Dikova-Favorska, 2015).

According to Andreeva, students with disabilities are characterized by such generalized problems of this social group as irresponsible attitude to their own lives, professions, lack of initiative in learning, lack of subjective behavior and desire to acquire new knowledge, professional and creative personal fulfillment, insufficiency of life experience, passivity in public work, 
indifference to health, insecurity, limited sources of new social experience due to lack of a wide range of social contacts; disorientation in social values; intolerant and consumer attitude to the environment; dependence of a student due to the family hyperopia; anxiety, conflict in connection with the violation of understanding with parents and parents' disbelief in the possibility of full social development of their child (Andreeva, 2013). The researcher identified a social worker as an important subject of work with students with disabilities in a higher education institution. The specialist in the inclusive education is entrusted with important functions such as: organizational; diagnostic and prognostic; preventive prevention; socio-therapeutic; communicative; human rights; psychological, socio-pedagogical; moral and humanisticfunctions (Andreeva, 2013). Hence, a social worker must be ready for interdepartmental and interdisciplinary interaction in everyday situations, identify ways of mutual assistance, be able to work in a team, and, most importantly, become a driving force in creating a tolerant attitude in society to people with disabilities. However, nowadays in many higher education institutions of Ukraine this specialist is not even included in the staff, and, consequently, a significant part of these functions are performed by curators of academic groups.

In the context of the problem of professional training of social workers to work with students with disabilities, research by Ukrainian educators who consider the formation of tolerant consciousness is of considerable interest. At present, the issues of tolerance, the formation of a tolerant consciousness and the education of a tolerant culture must be discussed not only at the level of equal rights and opportunities but also at the level of responsible duties. We can identify the main areas of tolerance in social workers: development of intercultural tolerance, education of openness and understanding of other peoples, the diversity of their cultures and histories; renunciation of violence, usage of peaceful means to resolve conflicts; altruism and respect for others, awareness and acceptance of personal identity and recognition of the diversity of the world around; improving knowledge and skills of interaction with clients on the basis of respect and acceptance of others; formation of skills of constructive, conflict-free communication and cooperation on the basis of tolerant values.

The pedagogy of tolerance is based on patient and attentive attitude to other people's beliefs. It is one of the means of solving the problems of students with disabilities and resolving conflict situations. The process of education of tolerance involves the purposeful organization of a positive experience of tolerance i.e. the creation of a space of direct or indirect interaction with other views or behavior of people, their communities, in other words the coexistence of differences.

Tolerance as a democratic value and having social roots is formed gradually. It is a complex, lengthy process that goes through the following stages: general awareness of who you are in a relationship; formation of a positive image of personality; communication by exchanging views with the identification 
of similarities and differences; defining the principles and conditions of communication and cooperation.

The most important task is to implement the principles of multicultural education that involves the development of the content of education that would help the subjects to understand the process of stereotypes about people with disabilities. The main principles of the pedagogy of tolerance are: the principle of cooperation; the principle of ecology of relationships; principle of jurisprudence; the principle of synergetism (Kostiuk, 2000).

The key to successful education of students with disabilities is specialized technical support that aims to provide these students with adaptive technical means and special learning technologies. Technical support should compensate for the functional limitations of students and ensure the principle of access to quality higher education for all students, regardless of the type of nosology and the severity of the disease. At all stages of technical support is provided the social and pedagogical support of students with disabilities in solving individual problems of mastering academic disciplines.

\section{CONCLUSIONS}

The task of social and pedagogical support is to create a comfortable living space for students with disabilities, learning strategies for overcoming difficulties in a particular problem situation, equipping with possible ways to solve life's problems. The organization of social and pedagogical support for students with disabilities depends on the readiness of academic and teaching staff to provide such support; trusting relationships between lecturers, the integrated academic group and students with disabilities; creating a situation of success and belief in the possibility of students with disabilities of the immediate environment and society in general; assessment not of the individual, but of his actions and knowledge; student-centered approach in the organization of the educational process.

Thus, social and pedagogical support of students with disabilities is: in the implementation of a comprehensive socio-educational impact on the level of social competence of students with disabilities and is revealed in the implementation of such main areas such as: organization of academic and teaching staff and tutors of academic groups for social competence of students with disabilities, in carrying out the work on the formation of tolerant communication with the student academic group and the development of social competence in students with disabilities.

The main principles of social and pedagogical support of students with disabilities are: individual approach; nature compliance; security; respect; establishing interdisciplinary, intersectoral and partnership cooperation; benevolence; tolerance; taking into account previous experience; reliance on positive characteristics and potential opportunities; development orientation; responsibility. 


\section{REFERENCES}

Andrieieva, M. (2013). Development of Social Competence of Students with Special Needs in Higher Educational Establishment: PhD (Education) Dissertation: Municipal Establishment Kharkiv Humanitarian-Pedagogical Academy. (in Ukrainian). URL: http://nbuv.gov.ua/UJRN/Nzkp_2015_38_3

Bohinska, Yu. (2013). Theory and Practice of Socio-Pedagogical Support for Students with Disabilities in Higher Educational Establishment: PhD (Education). (in Ukrainian)

Hluzman, O., Shchekolodkin, V., Podobiedova, T. Yu., \& Chuieva, O. (2006). Education of Students with Special Needs in High School: Simferopol Yalta. (in Ukrainian)

Dikova-Favorska, O. (2015). Creative Method of Educating Young People with Disabilities: Contemporary Social Problems in Terms of Sociology of Management: Collection of Scientific Papers: Donetsk State University of Management, 10 (116 Sociology of Public Administration; Series Special and Branch Sociologies), 324. (in Ukrainian)

Kostiuk, I. (2000). 20+1 Lesson Syllabus on Civic Education on «Tolerance» (I. Kostiuk \& P. Kendzior, Edit.). Publishing Department of Lviv Polytechnic International Institute of Education, Culture and Relations with Diaspora. (in Ukrainian)

Pichuhina, T. (2009). Support of the Need to Monitor the Education of Students with Disabilities in Higher Educational Establishment: Collection of Scientific Papers Kamianets-Podilskyi National University, 12, 92-95. KamianetsPodilskyi. (in Ukrainian). URL: http://www/nbuv/gov.au/porta/soc_ gum/ znpkp/Sp/2009_12/24.pdf

Alieksieienko, T., Zhdanovych, YU., Malyshonevskyi, R., Kunytsia, T., \& Serhieieva, N. (2017). Social-Pedagogical Support for Children and Students: monograph. LLC Zadruha. (in Ukrainian)

Vehner, I. (Edit.). (2019). Statistical Yearbook of Ukraine for 2018. State Statistics Service of Ukraine. (in Ukrainian)

Talanchuk, P., Kolchenko, K., \& Nikulina, H. (2004). Support for Students with Special Need in the Integrated Education Environment: Teaching Guide. Sotsinform. (in Ukrainian)

\section{СОЦАЛЬНО-ПЕДАГОГІЧНА ПІДТРИМКА СТУДЕНТІВ 3 ІНВАЛІДНІСТЮ У ЗАКЛАДАХ ВИЩОЇ ОСВІТИ}

Спіріна Тетяна, кандидат педагогічних наук, доцент кафедри соціального виховання та соціальної роботи Інституту гуманітарних наук, Київський унівесритет імені Бориса Грінченка, бульвар Ігоря Шамо, 18/2, 02000 Київ, Україна, t.spirina@kubg.edu.ua 
Ірабовска Барбара, доцент, факультет мистецтв та освітні наук, Інститут педагогіки факультету соціальних наук, Сілезький університет в Катовіцах, вул. Бєльська, 62, 43-400 Цешин, Польща, barbara.grabowska@us.edu.pl

Лях Тетяна, кандидат педагогічних наук, доцент, завідувач кафедри соціальної педагогіки та соціальної роботи Інституту гуманітарних наук, Київський унівесритет імені Бориса Грінченка, бульвар Ігоря Шамо, 18/2, 02000 Київ, Україна, t.liakh@kubg.edu.ua

У статті розглянуто питання навчання студентів з інвалідністю в закладах вищої освіти, підкреслено важливість та зазначено особливості соиіально-педагогічної підтримки, яка враховує основні моменти, які викликають труднощі у даної категорії при отриманні освітніх послуг. Визначені перспективні напрямки розв'язання проблем щодо організачіі підтримки студентів з інвалідністю у середовищі закладу вищої освіти. Розуміння сутності соціально-педагогічної підтримки студентів з інвалідністю в закладах вищої освіти передбачає, насамперед, знання специфіки різних видів порушень розвитку, виявлення наявних проблем, потреб та можливостей таких студентів, а також створення доцільних умов в освітньому середовищі для надання їм необхідної допомоги.

Зростання чисельності людей з інвалідністю в Украйні висуває низку проблем, пов'язаних з їх адаптацією, соціалізацією, зокрема з освітою та працевлаштуванням. Особливе місие в системі вищої освіти України займає інтегрована форма навчання студентів з інвалідністю разом з іншими студентами, головною умовою якої є забезпечення рівного доступу до навчання, позанавчальної діяльності, рівних прав на отримання вищої освіти.

Створення відповідних умов для навчання та розвитку студентів з інвалідністю у закладах вищої освіти, опанування знаннями, навичками, компетентностями є важливою складовою процесу інтеграції молоді з інвалідністю в суспільство. У сучасних умовах доступність вищої освіти для інвалідів є гострою соціальною і педагогічною проблемою, яка пов'язана із формуванням иілісного бачення й специфіки соиіально-педагогічного прочесу.

Ключові слова: заклад вищої освіти, інтегрована група, студенти з інвалідністю, освіта, навчання.

Received: 30.08 .2020

Accepted: 26.11.2020 